\title{
Characterization and Risk Assessment of the Collapse of the Woody Stand of Ecosystems of the Fathala Forest (Saloum Delta Biosphere Reserve-Senegal)
}

\author{
Eric Kaly ${ }^{1 *}$, Oumar Sarr ${ }^{1}$, Sékouna Diatta ${ }^{1}$, Abdoul Aziz Diouf ${ }^{2}$, Djibril Diouck ${ }^{3}$, Daouda Ngom ${ }^{1}$ \\ ${ }^{1}$ Laboratory of Plant Ecology and Eco-hydrology, Department of Plant Biology, Cheikh Anta Diop University, Dakar, Senegal \\ ${ }^{2}$ Ecological Monitoring Center for The Management of Natural Resources (CSE), Fann Residence, Dakar, Senegal \\ ${ }^{3}$ National Parks Directorate, Ministry of Environment and Sustainable Development, Dakar, Senegal \\ Email: *kalyeric@gmail.com
}

How to cite this paper: Kaly, E., Sarr, O., Diatta, S., Diouf, A.A., Diouck, D. and Ngom, D. (2021) Characterization and Risk Assessment of the Collapse of the Woody Stand of Ecosystems of the Fathala Forest (Saloum Delta Biosphere Reserve-Senegal). American Journal of Plant Sciences, 12, 975-993.

https://doi.org/10.4236/ajps.2021.127066

Received: June 2, 2021

Accepted: June 27, 2021

Published: June 30, 2021

Copyright $\odot 2021$ by author(s) and Scientific Research Publishing Inc. This work is licensed under the Creative Commons Attribution International License (CC BY 4.0).

http://creativecommons.org/licenses/by/4.0/

\begin{abstract}
The objective of this study is to characterize and assess the risk of collapse of woody plant formations in the Fathala forest. In recent years, this forest has suffered a sharp reduction in its plant cover to the point of compromising the survival of populations of certain animal species such as the Red colobuses. The methods used are respectively constituted by the transect method, the dendrometric statements method and that of establishing the red list of ecosystems of the IUCN. The specific richness comprises 56 species divided into 47 genera and 22 families. The density is higher in the unfenced area (369 ind/ha in clear forest and $53 \mathrm{ind} / \mathrm{ha}$ in gallery forest) compared to the fenced area (160 ind/ha in clear forest versus $48 \mathrm{ind} / \mathrm{ha}$ in gallery forest). A study of the plant formations shows a strong degradation of the ecosystems passing from a clear and dry Sudanese forest to a wooded savannah. The cover rate in the fenced area is $20 \%$ in gallery forests and $25 \%$ in clear forests; in the unfenced area, it is $19 \%$ and $23 \%$ in gallery forests and clear forests, respectively. The application of the IUCN criteria shows an annual rate of collapse is -6 ind/ha in gallery forests and -4 ind/ha in clear forests. The annual rate of cover collapse would be $-3.75 \%$ and $-2.9 \%$ for gallery forests and clear forests, respectively. These results classify the forest in the Critically Endangered category. The main factors responsible for this degradation are, among others, anthropogenic actions and climatic pejoration. These results could constitute a basic tool for undertaking an improvement in the management of this forest, which is a living environment for an animal species.
\end{abstract}




\section{Keywords}

Plant Formation, Woody Stand, Assessment, Collapse of Density and Cover

\section{Introduction}

Senegal's forest formations, like those of many Sahelian countries, are prone to relatively significant degradation, marked by a decrease in wooded areas, a reduction in the density of species and a change in their structure and function [1]. The alteration of ecosystems is more marked in the Sudano-Sahelian zone due to the combined action of climatic pejoration and increasingly significant anthropogenic pressures on plant and soil resources [2]. This state of degradation has not spared protected areas as the Fathala Forest [3]. These important decreases in biodiversity observed in the Fathala Forest are linked to the drought, which has become permanent and generalized in all West African countries for more than two decades [4]. According to [4], the degradation of the Fathala Forest is very rapid and the forest galleries are very threatened. The savannah becomes more and more open with a decrease in the number of species and rarefaction of forest species. Anthropogenic pressure, such as abusive cutting of the trees by local people, as well as the selective exploitation of wood by the sawmill (established in the Fathala Forest before its integration into the Park in 1986), are the main causes of the decrease in tree density, especially of Guinean essences. Initial analyses by [5] blamed the impact of late fires and overgrazing for the degradation of the Fathala Forest. This practice causes strong changes in the physiognomy and composition of the vegetation and prevents the regeneration of forest essences [5]. These changes also affect protected areas such as the Fathala Forest, which is home to a northern population of Colobus badius temminckii from Africa [3]. The climatic causes of this degradation, including drought, are difficult to control. However, better management and control of anthropogenic actions can mitigate threats to these ecosystems [2]. In order to better plan actions to slow the rate of decline, secure the future functions of these ecosystems for human use, and promote investment in ecosystem management [6], it would be necessary to understand the risks that threaten this biodiversity. For this purpose, the International Union for the Conservation of Nature (IUCN) has set up criteria for evaluating ecosystems to develop a better plan of action to slow the rate of decline, to guarantee the future functions of ecosystems for human use and to promote investment in their management [6]. Through the identification of species threatened with extinction, the IUCN Red List criteria offer information to governments and society on the current status of biodiversity [7] and trends in extinction risk [8]. These criteria also provide data to formulate conservation priorities and management strategies [9]. Knowledge of the characteristics of this plant population makes it possible to understand these ecosystems with worrying degradations in order to propose urgent rehabilitation strate- 
gies. The present study thus focuses on making a comparative analysis of the structural variability of the woody stand and to characterize the woody vegetation on the basis of an evaluation of the density of the woody cover of the forest (clear forests and gallery forests in the private and public zone) of the Saloum Delta Biosphere Reserve. Therefore, in order to conceptually clarify this simple and widely applicable risk assessment process, we have chosen to focus on the risks of biodiversity collapse as the primary objective of the establishment of the Red List of ecosystems.

\section{Materials and Methods}

\subsection{Presentation of the Study Area}

The study was carried out in the Fathala Forest located between $13^{\circ} 41^{\prime} \mathrm{N}$ latitude and $16^{\circ} 30^{\prime} \mathrm{W}$ longitude (Figure 1). It is located in the Sudanese climatic zone. This Sahelo-Sudanese type climate is characterized by two seasons during the year: a rainy season which extends from late June to mid-October, and a dry season of 7 to 9 months from October to May.

It constitutes the mainland part of the Saloum Delta National Park. This forest is one of the central nuclei of the Saloum Delta Biosphere Reserve (RBDS). The RBDS is located on the coasts of West Africa, at central western Senegal (Figure 1), in the estuarine part of the Sine-Saloum, of Diomboss and of Bandiala hydrographic basin, on the Gambian border [10]. The Fathala Forest was classified in 1934 and attached to the Saloum Delta National Park in 1986 [11]. The forest covers an area of 7300 ha of which 2000 ha are fenced and devoted to the private reserve. Overall, the relief of the region is very flat and remains inferior at 0.5 meter in elevation. The only elevations observed are sand cliffs, dunes and shell mounds (anthropogenic accumulations) that can reach up to five meters [10]. The soil is generally sandy with some areas possessing an outcrop of a lateritic layer with concretions [5].

\subsection{Study Methods}

\subsubsection{Vegetation Surveys}

The study of the woody stand of terrestrial ecosystems of the Fathala Forest was made on the basis of sampling. Sampling used the transect method. A total of four west-east orientation transects were chosen of different lengths according to the ecosystems. In gallery and clear forests, the transects are $1.5 \mathrm{~km}$ and $2 \mathrm{~km}$ long, respectively. The geographical position of these transects (variation in the distribution of the woody stand across each site) would be fairly representative of the Fathala Forest. Overall, 24 floristic surveys were sampled, including 16 floristic surveys in the unfenced area ( 8 at gallery forest level and 8 at clear forest level) and 8 in the private zone ( 4 at gallery forest level and 4 in the clear forest). The sampling unit is a rectangle plot of $50 \mathrm{~m} \times 20 \mathrm{~m}$, i.e. a survey area of 1000 $\mathrm{m}^{2}$ for the study of Sudanese vegetation [12]. In the forest galleries, couples of floristic surveys are juxtaposed on either side of the bed of the watercourse, at a 
distance of $250 \mathrm{~m}$ along the transect. For clear forests, the same methodology is used, couples of floristic surveys are positioned on either side of the transect line. The geographic coordinates of each floristic survey were determined using GPS in order to materialize the different sites (Figure 1). This working method is comparable to that used by [3] and [13].

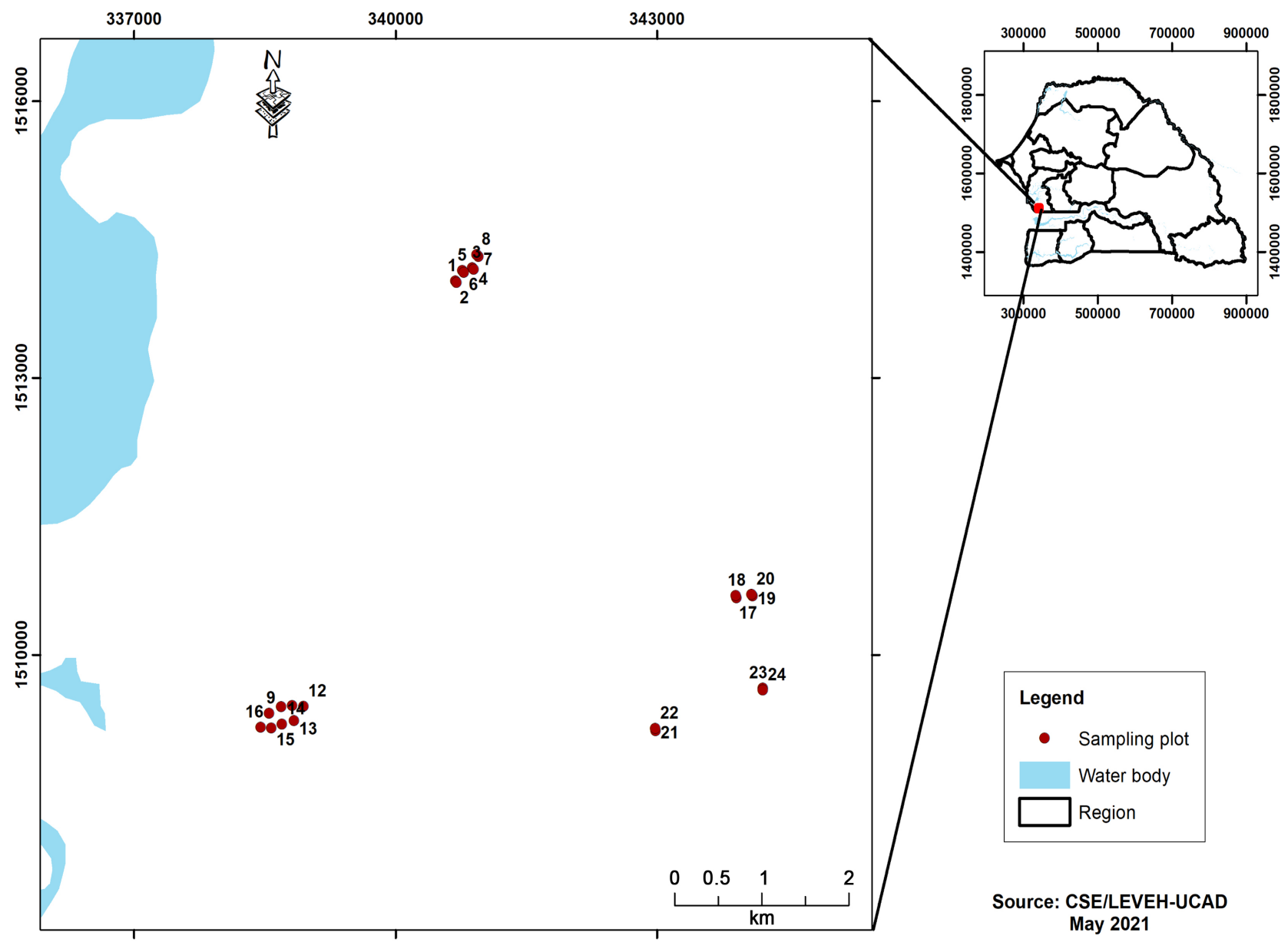

Figure 1. Map of the Fathala forest showing the position of the floristic surveys.

Dendrometric measurements were carried out to evaluate some dimensional parameters:

*the circumference at a height of $130 \mathrm{~cm}$ from the ground for all individuals measuring over $150 \mathrm{~cm}$. These individuals are considered to be the first shelter of the Colobus badius temminckii from Africa against predators,

*the height of the first branch,

* the height of the trees,

*the distance between two trees by the nearest individual method,

* recovery rate for each plot.

The inventory of all plant species in all the plots was carried out. The botanical samples were identified in the field using the "Flore du Sénégal" [14] and the book: “Arbres, arbustes et lianes d'Afrique de l'Ouest” [15]. 


\subsubsection{Data Treatment}

The data obtained were processed using EXCEL, XLStat and Minitab.16 software which were used to classify the numerical data and to construct the graphs. These software were used to calculate a certain number of ecological parameters, the specific richness, the real density, the relative frequency, the specific diversity of the woody stand of the Fathala Forest, to characterize the woody vegetation and to appreciate its degree of homogeneity.

The specific richness was evaluated from the total richness and the average specific richness. The total specific richness is the total number of species in the stand considered in a given ecosystem [16]. The average specific richness corresponds to the average number of species per survey for a given sample.

Frequential analysis: it is a method that consists of appreciating the distribution of species through surveys. The frequency of presence provides information on the distribution of a species in a stand. It can be expressed as an absolute value or as a percentage (\%). In \%, it is estimated by the following formula [17]:

$$
F=\frac{N r_{i}}{N r} \times 100
$$

$F=$ frequency of presence expressed as a percentage $(\%) ; N r_{i}=$ number of surveys where species $i$ is met and

$N r=$ number of surveys.

Density: this is the number of individuals per unit area. It is expressed in number of individuals/ha. The observed density or real density was determined.

The observed density or real density is obtained by the ratio of the total number of individuals in the sample $\left(N_{i}\right)$ by the sampled area unit $(S)$. It is expressed as the number of individuals per hectare $\left(\mathrm{n} \mathrm{ha}^{-1}\right)$. It is calculated from the following formula:

$$
D_{o b}=\frac{N_{i}}{S}
$$

$D_{o b}=$ observed density; $N_{i}=$ total number of species $i$ in the sample considered and $S=$ sample area in ha.

Assessment of diversity: the diversity index $\left(H^{P}\right)$ from Shannon Weaver (1949) and the regularity from Pielou (E) were used. The Shannon index is the most commonly used, it expresses the relative importance of species in a given environment. Its value gives an estimate of the uncertainty with which we can correctly predict the species to which the next individual collected belongs. The index is minimum when all individuals belong to the same species. It is maximum when each individual represents a distinct species [18]. It is given by the following relation:

$$
H^{\prime}=-\sum_{i=1}^{S} p_{i} \log _{2} p_{i}
$$

with $p(i)=n_{i} / N$ where $n_{i}$ is the number of individuals for species $i$ and $N$ is the total effective (individuals of all species). 
According to [19], the Pielou regularity index appears to be a more rigorous comparison term. It is between 0 and 1 and tends towards 0 when all the individuals belong to a single species. It tends towards 1 when each species is represented by the same number of individuals. Its value is obtained using the following formula:

$$
E=\frac{H^{\prime}}{H_{\max }^{\prime}}
$$

with $H$ = Shannon index; $H_{\max }^{\prime}=\log _{2} S, S$ being the total specific richness.

Recovery: it is given by the ratio as a percentage of the sum of the areas of the crown of all the trees projected vertically to the ground on the sampled area.

The regeneration rate of the stand is given by the percentage ratio between the total number of young plants (circumference $<10 \mathrm{~cm}$ ) and the total number of the stand [20]:

$$
\text { RRS }=\frac{\text { Total number of young plants }}{\text { Total number of the stand }} \times 100
$$

The total population of the stand comprising both young plants and adult plants.

The specific importance of regeneration is obtained from the percentage ratio between the number of young plants of a species and the number of young plants counted [21].

$$
\text { SIR }=\frac{\text { Number of young plants of a species }}{\text { Total number of young plants counted }} \times 100
$$

\subsubsection{Assessment of the State of Ecosystems and Application of Criteria Defined by IUCN}

The IUCN developed ecosystem collapse risk assessment method can be applied to any consistent classification of ecosystems. A generic risk assessment protocol developed by IUCN requires clearly well-defined assessment units. It requires the flexibility to assess risks across contrasting ecosystems. The biological and environmental characteristics, as well as the organization scales are very varied, and the levels of knowledge available are different.

\section{Results}

\subsection{Specific Richness}

The diversity of a plant stand is often measured by the specific richness. In our study we encountered 56 species divided into 47 genera belonging to 22 botanical families (Table 1). Also good in unfenced and fenced areas, the specific richness is similar between gallery forests and clear forests. The average specific richness is 4.31 species per survey in the Fathala Forest. It varies depending on the area and the plant formation; this being higher in clear forests than in gallery forests (Table 1). 
Table 1. Structural parameters of woody vegetation in Fathala forest.

\begin{tabular}{cccccc}
\hline & \multicolumn{2}{c}{ Unfenced area } & \multicolumn{2}{c}{ Fenced area } & \\
\cline { 2 - 5 } Ecological Parameters & $\begin{array}{c}\text { gallery } \\
\text { forest }\end{array}$ & $\begin{array}{c}\text { clear } \\
\text { forest }\end{array}$ & $\begin{array}{c}\text { gallery } \\
\text { forest }\end{array}$ & $\begin{array}{c}\text { clear } \\
\text { forest }\end{array}$ & $\begin{array}{c}\text { Fathala } \\
\text { forest }\end{array}$ \\
\hline Specific richness (S) & 25 & 27 & 14 & 13 & 56 \\
Average specific richness & 3.87 & 4.62 & 3.50 & 5.25 & 4.31 \\
\hline
\end{tabular}

\subsection{The Structural Parameters of Vegetation}

\subsubsection{Frequential Analysis}

The diversity of the woody flora was appreciated by using the distribution of species in the different taxonomic groups (genera, families). The centesimal frequencies are variable in the different zones (Table 2). In addition, in the Fathala forest no species are present in all the surveys that is to say at a frequency of $100 \%$ (Table 2).

Only two species (Daniellia oliveri (Rolfe) Hutch. \& Dalz and Acacia macrostachya Reichenb. ex Benth) are present in $75 \%$ of the surveys (Table 2). They are followed by Detarium senegalense Gmel, Erythrophleum guineense G. Don, Combretum glutinosum Perr. ex DC, Combretum paniculatum Vent, Terminalia avicennioides Guill. \& Perr, Terminalia macroptera Guill. \& Perr, Anthostema senegalense A. Juss, Pterocarpus erinaceus Poir, Azadirachta indica A. Juss, Prosopis africana (Guill. \& Perr.) Taub and Chlorophora regia A. Chev which are present in only half of the surveys of the two zones (Table 2). This distribution of species is variable according to the different area (gallery forests and clear forests).

Table 2. List and centesimal frequencies of woody species in the Fathala Forest in function to the zones (fenced and not fenced) according to the forests (clear and gallery).

\begin{tabular}{|c|c|c|c|c|c|}
\hline \multirow[b]{2}{*}{ Family } & \multirow{2}{*}{$\begin{array}{c}\text { Areas } \\
\text { Species }\end{array}$} & \multicolumn{2}{|c|}{ Not closed } & \multicolumn{2}{|c|}{ Closed } \\
\hline & & $\begin{array}{c}\text { gallery } \\
\text { forest }\end{array}$ & $\begin{array}{l}\text { clear } \\
\text { forest }\end{array}$ & $\begin{array}{c}\text { gallery } \\
\text { forest }\end{array}$ & $\begin{array}{l}\text { clear } \\
\text { forest }\end{array}$ \\
\hline \multirow{3}{*}{ Anacardiaceae } & Anacardium occidentale $\mathrm{L}$. & 0 & 12.5 & 0 & 0 \\
\hline & Lannea acida A.Rich. & 12.5 & 0 & 0 & 0 \\
\hline & Sclerocarya birrea (A. Rich.) Hochst. & 0 & 12.5 & 0 & 0 \\
\hline Annonaceae & Annona senegalensis Pers. & 0 & 12.5 & 0 & 0 \\
\hline Apocynaceae & Voacanga africana Stapf. & 12.5 & 0 & 0 & 0 \\
\hline Bignoniaceae & Newbouldia laevis (P. Beauv.) Seem. & 0 & 12.5 & 0 & 0 \\
\hline Bombacaceae & Adansonia digitata $\mathrm{L}$. & 0 & 12.5 & 0 & 0 \\
\hline \multirow[t]{2}{*}{ Capparaceae } & Crateva religiosa Forst. f. & 12.5 & 0 & 0 & 0 \\
\hline & Combretum glutinosum Perr. ex DC. & 0 & 12.5 & 0 & 50 \\
\hline \multirow[t]{2}{*}{ Combretaceae } & Combretum nigricans Lepr. ex Guill. \& Perr. & 0 & 0 & 0 & 75 \\
\hline & Combretum paniculatum Vent. & 25 & 0 & 0 & 50 \\
\hline
\end{tabular}




\section{Continues}

\begin{tabular}{|c|c|c|c|c|c|}
\hline & Combretum tomentosum G. Don. & 0 & 0 & 25 & 0 \\
\hline \multirow{3}{*}{ Combretaceae } & Guiera senegalensis J. F. Gmelin. & 0 & 0 & 0 & 25 \\
\hline & Terminalia avicennioides Guill. \& Perr. & 0 & 12.5 & 0 & 50 \\
\hline & Terminalia macroptera Guill. \& Perr. & 0 & 50 & 0 & 50 \\
\hline \multirow[t]{8}{*}{ Euphorbiaceae } & Anthostema senegalense A. Juss. & 12.5 & 0 & 75 & 0 \\
\hline & Acacia macrostachya Reichenb. ex Benth. & 37.5 & 0 & 50 & 75 \\
\hline & Afromorsia laxiflora (Benth.) Harms. & 0 & 12.5 & 0 & 0 \\
\hline & Cassia sieberiana DC. & 0 & 0 & 50 & 0 \\
\hline & Cordyla pinnata (Lepr.) Milne-Red. & 0 & 0 & 0 & 25 \\
\hline & Daniellia oliveri (Rolfe) Hutch. \& Dalz. & 12.5 & 62.5 & 0 & 25 \\
\hline & Detarium senegalense Gmel. & 12.5 & 0 & 25 & 0 \\
\hline & Dialium guineense Willd. & 37.5 & 0 & 0 & 0 \\
\hline \multirow[t]{7}{*}{ Fabaceae } & Dichrostachys cinerea (Linn.) Wight \& Arn. & 0 & 25 & 0 & 0 \\
\hline & Erythrophleum guineense G. Don & 62.5 & 0 & 25 & 0 \\
\hline & Faidherbia albida (Del.) Chev. & 0 & 0 & 25 & 0 \\
\hline & Parkia biglobosa (Jacq.) Benth. & 0 & 12.5 & 0 & 0 \\
\hline & Piliostigma reticulatum (DC.) Hochst. & 25 & 37.5 & 0 & 0 \\
\hline & Prosopis africana (Guill. \& Perr.) Taub. & 0 & 37.5 & 0 & 50 \\
\hline & Pterocarpus erinaceus Poir. & 0 & 37.5 & 0 & 50 \\
\hline \multirow[t]{2}{*}{ Loganiaceae } & Strychnos spinosa Lam. & 0 & 12.5 & 0 & 0 \\
\hline & Azadirachta indica A. Juss. & 75 & 25 & 0 & 0 \\
\hline \multirow[t]{3}{*}{ Meliaceae } & Khaya senegalensis (Desr.) A. Juss. & 0 & 12.5 & 0 & 0 \\
\hline & Trichila emetica Vahl. & 0 & 12.5 & 0 & 0 \\
\hline & Antiaris africana Engl. & 13 & 0 & 0 & 0 \\
\hline \multirow[t]{2}{*}{ Moraceae } & Chlorophora regia A. Chev. & 12.5 & 0 & 25 & 0 \\
\hline & Ficus asperifolia Miq. & 25 & 0 & 50 & 0 \\
\hline Myrtaceae & Eucalyptus alba Muell. & 0 & 12.5 & 0 & 0 \\
\hline Ochnaceae & Lophira lanceolata Van Tiegh. ex Keay & 0 & 12.5 & 0 & 0 \\
\hline Sapindaceae & Aphania senegalensis (Juss. ex Poir.) Radlk. & 0 & 12.5 & 0 & 0 \\
\hline
\end{tabular}

\subsubsection{Density}

The observed density (real density) of the different areas is consigned in Table 3. In the unfenced area, the observed density is 53 feet/hectare at the level of forest galleries and $369 \mathrm{feet} / \mathrm{hectare}$ at the level of clear forests. At the level of the fenced area, it is $48 \mathrm{feet} /$ hectare at the level of galleries forest and 160 feet/hectare at the level of clear forests (Table 3).

- In the unfenced area, at gallery forest level Azadirachta indica A. Juss, Dialium guineense Willd., Erythrophleum guineense G. Don are the dominant species with 14, 09 and 07 individuals per hectare respectively. While in the 
clear forest Daniellia oliveri (Rolfe) Hutch. \& Dalz, Terminalia macroptera Guill. \& Perr and Piliostigma reticulatum (DC.) Hochst with 290, 23 and 09 individuals per hectare, respectively, are the dominant species.

- In the fenced area, at level of the forest galleries Acacia macrostachya Reichenb. ex Benth, Anthostema senegalense A. Juss, Cassia sieberiana DC and Detarium senegalense Gmel are the dominant species with 10, 10, 08 and 05 individuals per hectare respectively. However, at the level of clear forests Acacia macrostachya Reichenb. ex Benth, Terminalia avicennioides Guill. \& Perr, Combretum nigricans Lepr. ex Guill. \& Perr, Combretum paniculatum Vent and Prosopis africana (Guill. \& Perr.) Taub with 40, 40, 30, 18 and 08 are the dominant species respectively. By comparing the two ecosystems, we see that the density is higher in clear forests compared to gallery forests.

\subsubsection{Recovery}

The recovery rate is on average $22 \%$ in the whole of the Fathala Forest. However, it varies according to the different ecosystems. Its value is strongly dependent on the presence of large trees with large crowns. At the level fenced area, it is $20 \%$ in gallery forests and $25 \%$ in clear forests. In the unfenced area, it is $19 \%$ and $23 \%$ in gallery forests and clear forests, respectively (Table 3).

Table 3. Structural parameters of woody vegetation in Fathala Forest.

\begin{tabular}{ccccc}
\hline \multirow{2}{*}{ Ecological parameters } & \multicolumn{2}{c}{ Unfenced area } & \multicolumn{2}{c}{ Fenced area } \\
\cline { 2 - 4 } & gallery forest & clear forest & gallery forest & clear forest \\
\hline Specific richness & 25 & 27 & 14 & 13 \\
Shannon index (bits) & 0.224 & 0.068 & 0.327 & 0.256 \\
Pielou regularity index & 0.042 & 0.008 & 0.077 & 0.042 \\
Real density (n ha ${ }^{-1}$ ) & 53 & 369 & 48 & 160 \\
Recovery rate (\%) & 20 & 25 & 19 & 23 \\
Stand Regeneration Rate (\%) & 97 & 67 & 94 & 90 \\
\hline
\end{tabular}

\subsubsection{Stand Structure}

The structure of the woody stand was established by the class distribution of heights and circumference in the different ecosystems of the Fathala Forest.

Distribution according to height: the Weibull distribution with three parameters (position parameter, scale or size parameter, shape parameter) of the woody stand according to the height classes shows:

- a straight asymmetric distribution (shape parameter between 1 and 3.6) characteristic of monospecific stands at the level of the clear forest of the unfenced aera and at the level of the gallery forest of the fenced aera (Figure 2). This distribution shows a predominance of young or low-height individuals between 1 and $5 \mathrm{~m}$ (Figure 2).

- an "inverted J" distribution (shape parameter less than 1) at the level of the gallery forest of the unfenced aera and at the level of the open forest of the 
fenced aera, characteristic of multispecies woody stands with the predominance of individuals whose height is between 2 and $5 \mathrm{~m}$ (Figure 2).

Distribution according to circumference: the Weibull distribution with three parameters (position parameter, scale or size parameter, shape parameter) of the woody stand according to the circumference classes shows an "inverted J" distribution (lower shape parameter 1) at the level of all of the two areas (unfenced and fenced areas) with a predominance of young individuals (Figure 3 ).

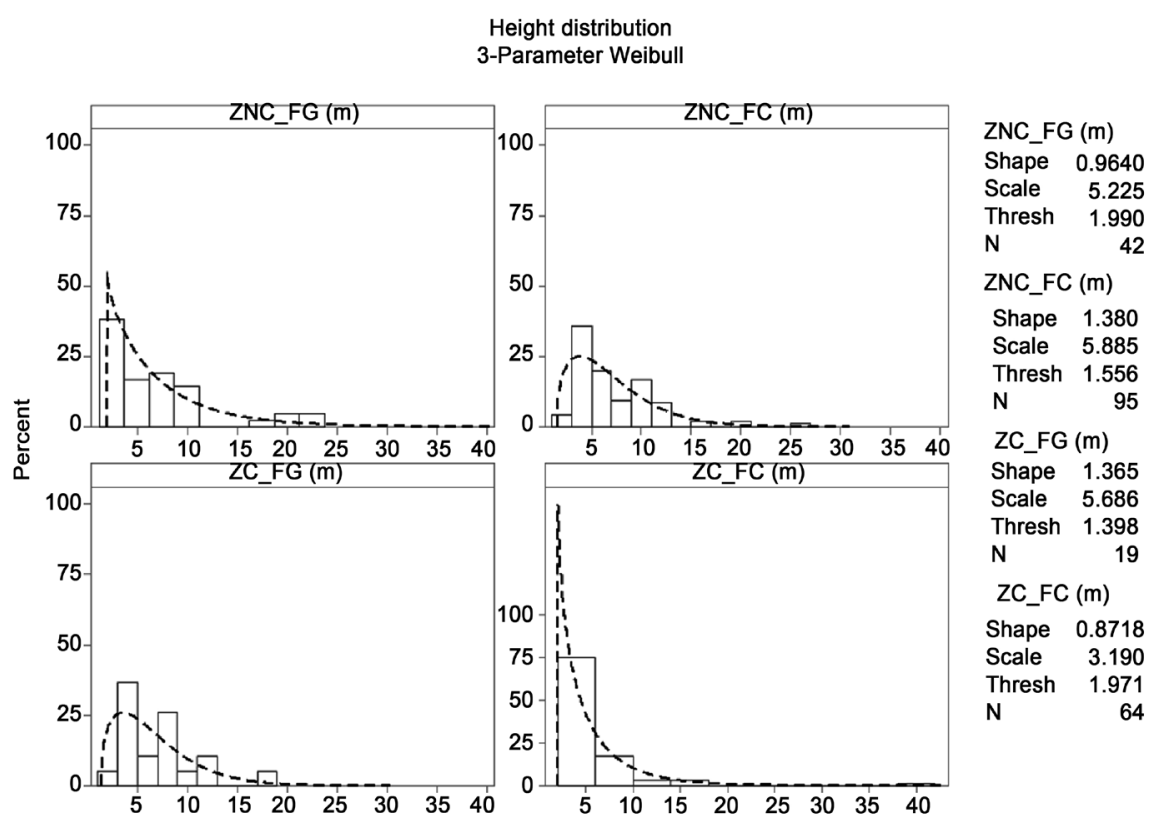

Figure 2. Height structure of the stand of the Fathala Forest according to areas: unfenced and fenced area according to the Weibull distribution with three parameters.

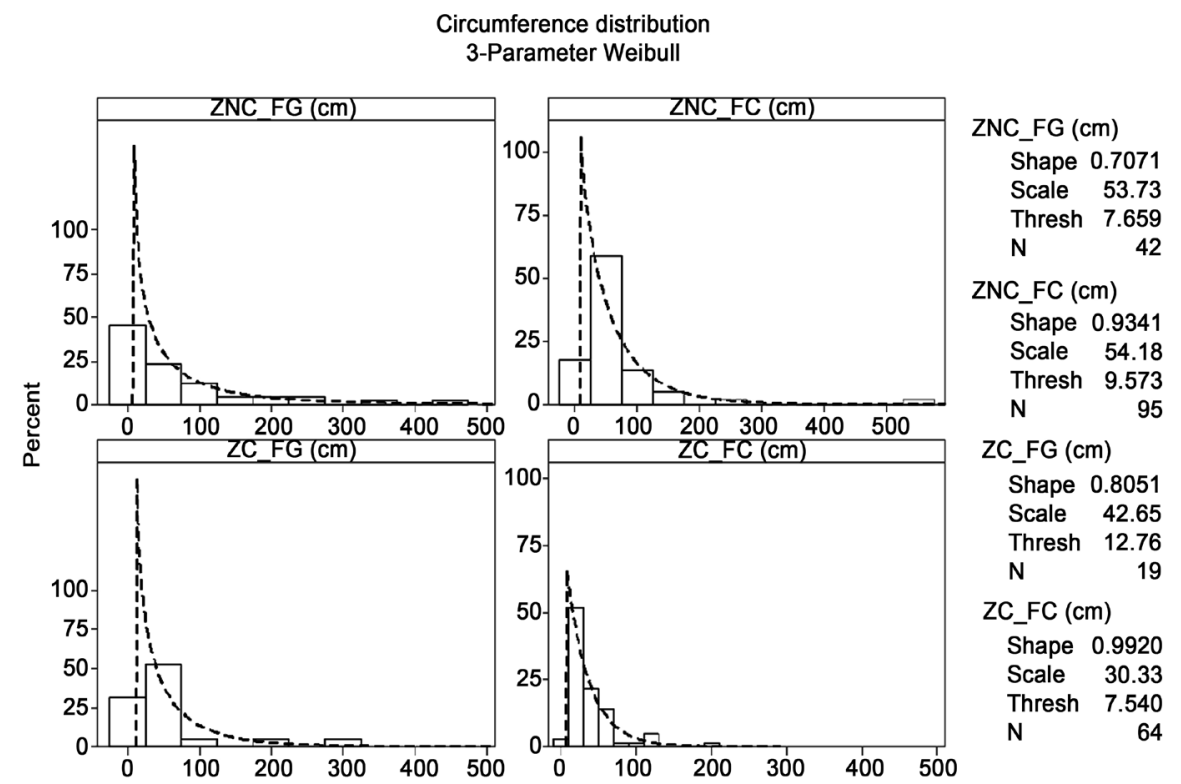

Figure 3. Structure in circumference of the stand of the Fathala forest according to areas: unfenced and fenced area according to the Weibull distribution with three parameters. 


\subsection{Regeneration}

In order to understand the basis of the dynamics of woody vegetation we evaluated the natural regeneration rate of the stand. It is $97 \%$ at the level gallery forests and $67 \%$ in clear forests of the unfenced area. In the fenced area, it is $94 \%$ for gallery forests against $90 \%$ for clear forests (Table 3). The importance of regeneration according to the different species was determined by calculation the specific index of regeneration (SIR) in the two areas (Table 4). In the unfenced area, the best regeneration was observed in species of the families of Caesalpiniaceae (Daniellia oliveri (Rolfe) Hutch. \& Dalz, 42.37\%) and of Apocynaceae (Saba senegalensis (A. DC.) Pichon 30.73\%) in gallery forest, while in clear forest Meliaceae (Azadirachta indica A. Juss, 55.39\%) are more abundant with important SIR. At the level fenced area, the Apocynaceae family (Saba senegalensis (A. DC.) Pichon 30.73\%) regenerates better in forest galleries, while in the clear forest the Combretaceae (Combretum glutinosum Perr. Ex DC. 27.59\%) are better represented with important values of SIR (Table 4).

Table 4. Specific index of regeneration (SIR) in \% in the two areas.

\begin{tabular}{|c|c|c|c|c|}
\hline \multirow{2}{*}{ Species } & \multicolumn{2}{|c|}{ Unfenced area } & \multicolumn{2}{|c|}{ Fenced area } \\
\hline & gallery forest & clear forest & gallery forest & clear forest \\
\hline Acacia macrostachya & 0.29 & 9.43 & - & 1.72 \\
\hline Acacia sieberiana & 0.51 & - & 0.36 & - \\
\hline Afromorsia laxiflora & - & 0.17 & - & 0.34 \\
\hline Afzelia africana & 0.07 & - & - & - \\
\hline Albizia ferruginea & 0.43 & - & - & - \\
\hline Albizia lebbeck & 0.07 & - & - & - \\
\hline Anacardium occidentale & - & 0.51 & - & - \\
\hline Annona senegalensis & - & 0.34 & - & - \\
\hline Anthostema senegalensis & 0.07 & - & 0.71 & - \\
\hline Aphania senegalensis & 0.58 & 0.67 & - & - \\
\hline Azadirachta indica & 8.75 & 55.39 & 0.36 & - \\
\hline Calotropis procera & - & - & 0.36 & - \\
\hline Capparis decidua & 0.07 & - & 2.86 & - \\
\hline Cola cordifolia & - & - & 0.36 & - \\
\hline Combretum aculeatum & - & 0.17 & - & - \\
\hline Combretum glutinosum & - & - & 0.71 & 27.59 \\
\hline Combretum micranthum & 0.14 & - & 15.71 & - \\
\hline Combretum nigricans & - & - & - & 15.17 \\
\hline Combretum paniculatum & 4.12 & - & 13.93 & 5.17 \\
\hline Cordyla pinnata & - & 0.17 & - & - \\
\hline Crateva religiosa & 3.69 & - & 0.36 & - \\
\hline Daniellia oliveri & 42.73 & 9.60 & - & 5.86 \\
\hline Detarium senegalense & 0.14 & - & 1.79 & 7.07 \\
\hline
\end{tabular}




\begin{tabular}{|c|c|c|c|c|}
\hline Continued & & & & \\
\hline Dialium guineensis & 0.72 & - & - & - \\
\hline Dichostachys cienerea & 0.29 & 7.07 & 8.57 & 12.07 \\
\hline Entada africana & - & 1.35 & - & 0.34 \\
\hline Erythrophleum guineensis & 0.51 & - & 7.14 & - \\
\hline Guiera senegalensis & - & - & - & 1.03 \\
\hline Lannea acida & 0.22 & 0.34 & - & - \\
\hline Lannea velutina & - & 1.85 & - & 0.52 \\
\hline Newbouldia laevis & - & - & - & 0.52 \\
\hline Parkia biglobosa & 0.14 & 1.18 & - & - \\
\hline Piliostigma reticulatum & 0.43 & 0.17 & 1.07 & - \\
\hline Pterocarpus erinaceus & - & 0.67 & - & - \\
\hline Saba senegalensis & 30.73 & 5.89 & 45.00 & - \\
\hline Sarcocephalus latifolia & 0.07 & - & - & - \\
\hline Sclerocarya birrea & - & 0.84 & - & 0.17 \\
\hline Securidaca longepedunculata & - & 0.17 & - & 0.17 \\
\hline Stereospermum kunthianum & 4.92 & - & 0.71 & - \\
\hline Strychnos spinosa & - & - & - & 0.34 \\
\hline Terminalia avicennioides & - & - & - & 17.41 \\
\hline Terminalia macroptera & - & 1.85 & - & 4.31 \\
\hline Trichila emetica & - & 0.84 & - & - \\
\hline Voacanga africana & 0.07 & - & - & - \\
\hline Ziziphus mauritiana & - & 1.35 & - & 0.17 \\
\hline Ziziphus mucronata & 0.22 & - & - & - \\
\hline
\end{tabular}

\subsection{Ecosystem Assessment According to the Criteria of the Red List of the International Union for Conservation of Nature (IUCN)}

To assess the state of ecosystems and the risk of the collapse at our study site, we synthesized different evidence, causes, mechanisms and pathways of decline into an assessment framework generic risk. To do this, we estimated the level of threat to the ecosystems. The UINC red list is based on five evaluation criteria (A, B, C, D and E), two of which are based on spatial distribution, two others concern the functioning and a last rarely evaluated criterion which takes into account global digital modelling of the risk of collapse. To estimate this "risk", the coverage rate of these different ecosystems was evaluated on the one hand over a specified time space of twenty years ranging from 1969 to 1989, then from 1989 to 2019 and on the other hand the population density was used over a forty-year period from 1972 to 2012. Finally, a projection of these two parameters, the coverage rate and the density, was carried out respectively in 2019 and 2022 (Table 5 \& Table 6). Our risk assessment model groups symptoms of collapse into three broad categories. Two of the three mechanisms produce distribution symptoms: 
- Criterion A: Continuous drop in distribution, which reduces the carrying capacity for dependent biota. This reduction is measured on the basis of one or more of the sub-criteria from A1 to A4. For our study, only the sub-criteria A3 and A4 were applied. Sub-criterion A3 corresponds to the reduction in the population predicted, deduced or assumed in the future. Sub-criterion A4 indicates the reduction in population noticed, estimated, deduced, predicted or assumed, over a period of time that should include both the past and the future, when the causes of the reduction may not have ceased or may not have been understood or are maybe not reversible. When the observation is direct, it is the sub-criterion A4a that is applied [22].

- Criterion B: Restricted expanse predisposes the system to the spatially explicit threats. This criterion is subdivided into two sub-criteria b1 and b2. For our model, the sub-criterion b2 was applied. Sub-criterion b2, area of occupancy (AOO) i.e., the territory occupied by a taxon within the extent of occurrence, excluding wandering individuals [22].

- Criterion C: Degradation of the abiotic environment, reducing the quality of habitat or the diversity of abiotic niches for biota. This criterion is subdivided into three sub-criteria (C1, C2, and C3) [22]. The sub-criteria C1 and C2 werer applied in this study. When the modification of abiotic parameters is observed during the last 50 years, sub-criterion C1 is applied. C2 is the modification of abiotic parameters calculated or estimated over the 50 years or period of 50 years including the present and the future (Table $5 \&$ Table 6).

Table 5. Evaluation of the recovery rate of the various ecosystems in 1969, 1989 and 2019 according to criteria for establishing the red list.

\begin{tabular}{cccccccccc}
\hline $\begin{array}{l}\text { Ecosystem } \\
\text { (Recovery } \\
\text { rate/year) }\end{array}$ & 1969 & 1989 & $1989-1969$ & ACR & F 2019 & A3 & A4a & A4C2 & Category \\
\hline $\begin{array}{c}\text { Forest } \\
\text { Gallery }\end{array}$ & 98 & 23 & -75 & -3.75 & -187.5 & CR & CR & VU & CR \\
Clear forest & 88 & 30 & -58 & -2.9 & -145 & CR & CR & VU & CR \\
\hline
\end{tabular}

ACR: Annual Collapse Rate; F: Forecasting of collapse; CR: Critically endangered; VU: Vulnerable; EN: Endangered.

Besides the recovery rate, the density observed in the two ecosystems of 1972 and 2012 was used to assess the degree of collapse.

Table 6. Woody population density between 1972-2012 compared to that estimated in 2022.

\begin{tabular}{|c|c|c|c|c|c|c|c|c|c|c|c|}
\hline $\begin{array}{l}\text { Ecosystem } \\
\text { (density/ha) }\end{array}$ & 1972 & 2012 & $2012-1972$ & ACR & 2022 & $\%$ F2022 & A3 & $\mathrm{A} 4 \mathrm{~b} 2$ & $\mathrm{~A} 4 \mathrm{C} 1$ & $\mathrm{~A} 4 \mathrm{C} 2$ & Category \\
\hline Forest gallery & 293 & 53 & -240 & -6 & -300 & -102.38 & CR & $\mathrm{EN}$ & & VU & CR \\
\hline Clear forest & 517 & 355 & -148 & -3.7 & -185 & -35.78 & VU & & VU & & CR \\
\hline
\end{tabular}




\section{Discussion}

The results of this study provide first information on the state of the woody vegetation in the forest of Fathala. The characterization of the woody stand revealed the presence of 56 species divided into 47 genera belonging to 20 families. The method of comparison of means [23] was applied to the specific richness by area. On average, we have identified more species in the unfenced area (25 species in gallery forest and 27 species in clear forest) than in the fenced area (14 species in gallery forest and 13 species in clear forest). It should be noted that the specific richness is a function of the number of floristic surveys of the sampled surface. It depends on the completeness of the inventory. Now the floristic surveys are never exhaustive because there is a problem of detectability of the species [24] [25]. Note, however, that specific richness is only one of the indicators, descriptor of biodiversity [26].

In addition, our analysis of the centesimal frequency showed the proliferation of certain species, normally dependent on drier environments, such as Combretum nigricans (75\%), Acacia macrostachya (75\%) and Daniellia oliveri (62.5\%) in clear forest and Anthostema senegalense (75\%), Azadirachta indica (75\%), Erythrophleum guineensis (62.5\%) and Dialium guineense (37.5), in gallery forest. Furthermore, this analysis of the centesimal frequency in all of these systems identified two so-called more frequent species, Acacia macrostachya and Daniella, present in 3/4 of the vegetation surveys. Similar results were obtained by [27] which shows a sharp decrease in the specific richness (44\%) and a proliferation of certain species from drier environments, such as Combretum nigricans in clear forest and Saba senegalensis, Anthostema senegalense, Dialium guineense and Aphania senegalensis in gallery forest. This proliferation of certain species with drier affinities is a good indicator of changes in the state of woody vegetation.

Our study revealed that the real density of the woody stand varies depending on the area. It is greater in the unfenced area (369 individuals/ha in clear forest and 53 individuals/ha in gallery forest) compared to the fenced area (160 individuals/ha in open forest versus 48 individuals/ha in gallery forest). This difference in density observed between the unfenced and fenced areas could be explained by the fact that the unfenced area remains open for grazing, unlike the fenced area. This activity favours the concealment of grains by the cattle, which would be at the origin of a high diversity [1]. This activity would be at the origin of the high density observed in the unfenced area. These densities compared to those observed in 1972 (293 individuals/ha in gallery forests and 517 individuals/ha) report a show very significant regression in the density of woody plants, both in clear forest and in gallery forest. A corollary of this decrease in diversity is the increase in the dominance of certain species, in particular Combretum nigricans, Acacia macrostachya and Daniellia oliveri in clear forest and, Anthostema senegalense, Dialium guineense, Aphania senegalensis and Saba senegalensis in gallery forest. It is contrary to the report [11] showing evaluation of the habitats 
in a protected area of the Saloum Delta Biosphere Reserve in the Fathala forest. The proliferation of these species reduces biodiversity at the forest level.

We found a recovery rate of $22 \%$ for the whole forest. However, this vegetation cover varies from one area to another. It is important at the level of clear forests compared to gallery forests. This reduction in plant cover observed at level gallery forests could be linked to climatic pejoration and especially to anthropogenic action [2]. These factors reduce the number of Guinean species (trees with large crowns) characteristic of gallery forests to the detriment of species in dry areas. Indeed, trees with large crowns contribute more to the covering up to a certain degree of covering [26]. This vegetation cover is function on the distribution of the woody stand. However, several types of distribution can be used (normal distribution, log-normal distribution, exponential distribution, Weibull distribution) to estimate the parameters from the observed data [28]. The Weibull distribution is more adequate because it is characterized by a great flexibility of use and presents a great variability of shape following to the values taken.

The distribution according to the size (circumference) of all the forests of the two areas shows that the population has a reversed "J" shaped structure translating the importance of young plants within this population. Indeed, it is dominated by individuals (88.5\%) whose circumferences are between 0 and 1.46 $\mathrm{m}$. The structure of the woody stand established following to the Weibull distribution with three parameters shows that the height of the trees generally varies between 1.60 and $26.70 \mathrm{~m}$. However, it should be noted that $78.5 \%$ of individuals in these two areas have heights between 1.60 and $8.30 \mathrm{~m}$. This reveals the importance of the shrubby stratum in clear forests and gallery forests. Analysis of the structure of these populations and field observations allow to indicate that the distribution is unimodal in most of the gallery forest in the fenced area and the clear forest in the unfenced area. This unimodal distribution is characteristic of even-aged stands. At the level of the gallery forest and the clear forest respectively of the fenced and unfenced area, the results from the adjustment to the Weibull distribution clearly show that this is a habitat where the predominance of a species or a restricted group of species is noted. This characteristic is in adequacy with the ecological characteristics of a strongly disturbed area [29].

The regeneration rate of the plant stand is $87 \%$ in the whole forest. It is higher in gallery forests ( $97 \%$ for the unfenced area and $94 \%$ the fenced area) than in clear forests ( $67 \%$ for the unfenced area and $90 \%$ for the fenced area). This difference could be explained by a good seed germination capacity observed in the forest galleries on account of water potential. The presence of water points in the forest galleries, constitute drinkers for wild animals which play an important role in the dissemination of seeds. Similar results were obtained in the area on natural regeneration of a species (Cordyla pinnata) [1].

Following the characterization of the woody stand, an assessment of the state of the ecosystems was carried out according to criteria for establishing the Red 
List of ecosystems of the UINC between 1969 and 2019 for the recovery rate and between 1972 and 2022 for density. Ideally, the criteria for establishing the Red List should identify ecosystems whose diversity, ecological functions and/or ecosystem services are risk of disappearing, since these three elements are closely linked and are important for conservation [30].

The Fathala forest located in a Sahelo-Sudanese climate, formerly wooded, has suffered the impact of episodes of repetitive droughts and abusive anthropogenic activity. A decrease in the recovery rate is observed, going from $98 \%$ in 1969 to $23 \%$ in 1989 at the level of forest galleries and $88 \%$ in 1969 to $30 \%$ in 1989 according to [27] [31]. From these results, compared to ours, an exhaustive ecosystem assessment study was carried out. In 30 years, the reduction in plant cover was $75 \%$ in the gallery forests and $58 \%$ in clear forests. The rate of regression would be $3.75 \%$ /year for gallery forests and $2.9 \%$ /year for clear forests. By referring to this rate of regression, our work on forest assessment forecasts over a period of twenty years ranging from 1989 to 2019, that the regression would be $187.5 \%$ in 2019 for gallery forests and $145 \%$ for clear forests, if no management plan is undertaken.

The application of Red List assessment criteria of ecosystems translates a level of collapse CR (critically endangered; according to the application of sub-criteria $\mathrm{A} 3$ and $\mathrm{A} 4 \mathrm{a}$ ) and VU (vulnerable; according to the application of the sub-criterion A4C2) [32] for gallery forests and clear forests. In short, depending on the collapse category for the recovery rate parameter, the Fathala forest would be in critical danger. The state of degradation of this ecosystem has already been underlined by [11] [27] and [31].

This impact did not spare the density of the woody stand. An evaluation of the density per hectare showed that this increased from 293 ind/ha in 1972 to 53 ind/ha in 2012 at the level of forest galleries and 517 ind/ha in 1972 to 355 ind/ha in 2012 at the level of clear forests, it went from 517 ind/ha in 1972 to 355 ind/ha in 2012. In forty years, the reduction in density is $240 \mathrm{ind} / \mathrm{ha}$, i.e., a rate of $6 \mathrm{ind} / \mathrm{ha} /$ year observed at the level of forest galleries and $148 \mathrm{ind} / \mathrm{ha}$, i.e., a rate of $3.7 \mathrm{ind} / \mathrm{ha} /$ year for clear forests. A decrease in the density of more stable natural plant formations is observed in favour of those more adapted ones. This is translated in the level of CR collapse observed as well in gallery forests and in clear forests. Starting from old data (1972) to recent data on the densities of plant formations, it may be predicted that the degradation of ecosystems is very advanced. These changes in vegetation cover and structure, accompanied by the development of species with drier affinities, constitute threats for certain animal species, especially the arboreal species Colobus badius temminckii from Africa who is arboreal.

\section{Conclusions}

The wooded surface of the forest has undergone profound modifications, with a decrease in the area both in the clear forest and in the gallery forests. However, it is at the level of gallery forests that the degradation is more accentuated. Today, 
this forest once described as a clear, dry Sudanese forest, has become a wooded savanna.

The evaluation of this forest by the criteria for establishing the Red List of ecosystems during these forty years has shown profound upheavals following anthropogenic and climatic actions. The phenomena of desertification have seriously disturbed the forest. That leads to situate this forest in the CR (critically endangered) collapse category, according to IUCN criteria.

\section{Conflicts of Interest}

The authors declare no conflicts of interest regarding the publication of this paper.

\section{References}

[1] Diop, F.N., Lykke, A.M. and Sambou, B. (2011) Régénération naturelle de Cordyla pinnata (Lepr. Ex. A. Rich.) Milne-Redh. Dans une savane soumise au feu et au pâturage. Science et changements planétaires/Sécheresse, 22, 186-191.

[2] Taibou, B., Akpo, L.E. and Diouf, A.A. (2017) Dynamique spatio-temporelle des écosystèmes du bassin versant du Ferlo (Nord-Sénégal). Journal of Animal Plant Sciences, 33, 5255-5273.

[3] Diouck, D. (1999) Adaptations aux modifications du milieu des Colobes bais (Colobus badius temmincki) de la forêt de Fathala, Parc National du Delta du Saloum, Sénégal. Thèse de $3 \mathrm{e}$ cycle, UCAD, Dakar.

[4] Lykke, A.M. (1996) How Gallery Forest Tums into Savanna an Example from Senegal. In: van der Maesen, L.J.G., et al., Eds., The Biodiversity of African Plants, Kluwer Academic Publishers, Dordrecht, 323-328.

https://doi.org/10.1007/978-94-009-0285-5_42

[5] Lykke, A.M. (1993) Description and Analyses of the Vegetation in Delta du Saloum National Park, Senegal. AAU Reports 33, AARHUS University Press, Aarhus, 90 p.

[6] Ayensu, E., Van Claasen, D.R., Collins, M., Dearing, A., Fresco, L., Gadgil, M., Zakri, A.H., et al. (1999) International Ecosystem Assessment. Science, 286, 685-686. https://doi.org/10.1126/science.286.5440.685

[7] Baillie, J.E.M., Hilton-Taylor, C. and Stuart, S.N. (2004) UICN Red List of Threatened Species. A Global Species Assessment. UICN, Gland and Cambridge. https://doi.org/10.2305/IUCN.CH.2005.3.en

[8] Butchart, S.H.M., Stattersfield, A.J., Bennun, L.A., Shutes, S.M., Akçakaya, H.R., et al. (2004) Measuring Global Trends in the Status of Biodiversity: Red List Indices for Birds. PLoS Biology, 2, 2294-2304. https://doi.org/10.1371/journal.pbio.0020383

[9] McCarthy, M.A., Thompson, C.J. and Garnett, S.T. (2008) Optimal Investment in Conservation of Species. Journal of Applied Ecology, 45, 1428-1435. https://doi.org/10.1111/j.1365-2664.2008.01521.x

[10] Direction des Parcs Nationaux (DNP) (2010) Plan de gestion du Parc National du Delta du Saloum (2010-2014). Dakar, 86.

[11] Galat-Luong, A., Galat, G. and Diouck, D. (1998) Evolution 1971-1996 des habitats d'une aire protégée de la Réserve de Biosphère du Delta du Saloum (Sénégal), la Forêt de Fathala: Recouvrement, densité et biodiversité des ligneux (document scientifique du Programme ORSTOM-UICN Etat des lieux et suivi écologique de la 
grande faune sauvage terrestre et de ses habitats dans la RBDS).

[12] Boudet, G. (1984) Manuel sur les pâturages tropicaux et les cultures fourragères. 4ème édition, Ministère de la Coopération, Manuel et Précis d'élevage 4, Paris, 254.

[13] Gatinot, B.L. (1974) Précision sur la répartition du Colobe bai (Colobus badius temmincki Kuhn, 1820) et de la mone de Campbell (Cercopithecus mona campbelli Waterhouse, 1838) en Sénegambie. Mammalia, 38, 711-716. https://doi.org/10.1515/mamm.1974.38.4.711

[14] Behraut, J. (1967) Flore du Sénégal. Edition Clairafrique, Dakar, $2^{\mathrm{e} e}$ édition, 485 p.

[15] Arbonnier, M. (2002) Arbres, arbustes et lianes des zones sèches d'Afrique de l'Ouest. CIRAD et Museum d'histoire naturel de Paris, Paris, 573 p.

[16] Ramade, F. (2003) Eléments d’Écologie: Écologie fondamentale. 3ème édition, Dunod, Paris, $690 \mathrm{p}$.

[17] Gning, O.N. (2008) Caractéristiques des ligneux fourragers dans les parcours communautaires de Khossanto (Kédougou, Sénégal Oriental). Mémoire de DEA en Biologie végétale, $\mathrm{UCAD}, 78 \mathrm{p}$.

[18] Legendre, L. and Legendre, P. (1984) Ecologie numerique. Tome I. Le traitement multiple des données écologiques. Masson, $260 \mathrm{p}$.

[19] Devineau, J.L., Lecordier, C. and Vuattoux, R. (1984) Evolution de la diversité spécifique du peuplement ligneux dans une succession préforestière de colonisation d'une savane protégée des feux (Lamto, Côte-d'Ivoire). Candollea, 39, 103-134.

[20] Poupon, H. (1980) Structure et dynamique de la strate ligneuse d'une steppe sahélienne au nord du Sénégal. Etudes \& Theses, ORSTOM, Paris, 307 p.

[21] Akpo, L.E. and Grouzis, M. (1996) Influence du couvert sur la régénération de quelques espèces ligneuses sahéliennes (Nord-Sénégal, Afrique occidentale). Webbia, 50, 247-263. https://doi.org/10.1080/00837792.1996.10670605

[22] Keith, D.A., Rodríguez, J.P., Rodríguez-Clark, K.M., Nicholson, E., Aapala, K., Alonso, A. and Benson, J.S. (2013) Scientific Foundations for an IUCN Red List of Ecosystems. PLoS ONE, 8, e62111. https://doi.org/10.1371/journal.pone.0062111

[23] Scherrer, B. (1984) Les comparaisons de moyennes. Biostatistique (ed. G Morin), 401-463.

[24] Gosselin, M. and Laroussinie, O. (2004) Biodiversité et gestion forestière Connaître pour préserver. Synthèse bibliographique. Cemagref Editions. 320.

[25] Deconchat, M. and Balent, G. (2004) Critères et indicateurs de gestion durable des forêts: la biodiversité. Revue forestière française.

[26] Ngom, D., Fall, T., Sarr, O., Diatta, S. and Akpo, L.E. (2013) Caractéristiques écologiques du peuplement ligneux de la réserve de biosphère du Ferlo (Nord Sénégal). Journal of Applied Biosciences, 65, 5008-5023. https://doi.org/10.4314/jab.v65i0.89644

[27] Diouck, D. and Akpo, L.E. (2007) Dégradation de la forêt de Fathala dans le parc national du delta du Saloum (Sénégal): Conséquences sur la conservation de la faune. IRD, Paris, 522-523.

[28] Husch, B., Beers, T. and Kershaw, J.J.R. (2003) Forest Mensuration. 4th Edition, John Wiley \& Sons, Hoboken.

[29] Agbani, P.O., Amagnide, A., Goussanou, C., Azihou, F. and Sinsin, B. (2018) Structure des peuplements ligneux des formations végétales de la forêt sacrée de Nassou en zone soudanienne du Bénin. International Journal of Biological and Chemical Sciences, 12, 2519-2534. https://doi.org/10.4314/ijbcs.v12i6.5

[30] Cardinale, B.J., Duffy, J.E., Gonzalez, A., Hooper, D.U., Perrings, C., Venail, P. and 
Naeem, S. (2012) Biodiversity Loss and Its Impact on Humanity. Nature, 486, 59-67. https://doi.org/10.1038/nature11148

[31] Diouck, D., Galat-Luong, A. and Galat, G. (1996) The Fathala Forest Red Colobus (Colobus badius temmincki): Twenty Years of Delay. Folia Primatologica, 67, 89.

[32] Rodríguez, J.P., Rodríguez-Clark, K.M., Baillie, J.E., Ash, N., Benson, J., Boucher, T. and Keith, D.A. (2011) Elaboration des Critères de l'UICN pour la Liste Rouge des Ecosystèmes Menacés. Conservation Biology, 25, 21.

https://doi.org/10.1111/j.1523-1739.2010.01598.x 